\title{
Response 5-phosphomevalonate Kinase Enzymes to Low Doses of Gamma Radiation and Its Related to the Production of Terpenoids Indole Alkaloids from Catharanthus rouses
}

\author{
I.M. Salama\#, G.M. Ali, Mohamed H.M. Abd EL-Megid \\ Natural Products Research Department (Biotechnology Branch), National Center for \\ Radiation Research and Technology (NCRRT), Egyptian Atomic Energy Authority \\ (EAEA), Cairo, Egypt.
}

\begin{abstract}
AMMA rays effect, on different dose levels on the production of ajmalicine as well $U$ as 5-phosphomevalonate kinase enzyme activety, was studied in Catharanthus roseus cell suspension cultures. The seedlings were taken from the young leaf puds and grown on MS solid medium for 7 weeks. Calli individual serially sub cultured by transfing to maintenance medium consisting of Gamborg's B5 medium. Cell suspensions were exposed to gamma rays after 4 weeks at dose levels of $1,1.5,2,2.5,3,3.5,4,4.5,5,5.5,6,6.5$, 7, 7.5 and 8Gy. Ajmalicine quantities were analyzed on VIS-spectrophotometer; also, the 5-phosphomevalonate kinase enzyme was particularly purified by ultrafiltration and activety analayzed, in addition, native PAGE electrophoresis was determined. 5-phosphomevalonate kinase enzyme bands and ajmalicine accumulation quantities were changed after the exposure to low doses from 1 to $6 \mathrm{~Gy}$, but the higher doses were lethal. The appropriated doses to activety of 5-phosphomevalonate kinase enzyme and Ajmalicine production were from 1 to 5Gy. Other dose levels (5.5 and 6Gy) did not affect on the 5-phosphomevalonate kinase enzyme activety and Ajmalicine production.
\end{abstract}

Keywords: Gamma rays, 5-phosphomevalonate kinase, Terpenoids indole alkaloids, Catharanthus roseus.

\section{Introduction}

Isopentenyl diphosphate (IPP) is the main precursor of all isoprenoid biosynthesis. Two pathways are known to indole alkaloids biosynthesis until now, the first pathway is Mevalonate (MVA) (Bach, 1995) and the second pathway is Shikimate (MEP2) (Lichtenthaler et al., 1997). The MVA pathway is supposed to be cytosolic and MEP pathway is localized in chloroplast (Schulte et al., 1999). Isoprenoid biosynthesis is important in higher plants for developments, metabolism, environmental stresses protection and resistance against microbial disease of the plants (Aerts et al., 1992). Signals components such as $\mathrm{Ca}^{2+} /$ ion fluxes, oxidative burst, nitric oxide, Jasmonate, medium alkalinization and cytoplasmic acidification, etc. have important role by elicitors for plant secondary metabolite accumulation (Zhao et al., 2005). All secondary metabolic products are very important in pharmaceutical industry, particularly drugs of cancer diseases. Hence, there is a strategic trend to increasing and improving the indole alkaloid production in vitro (Ramani \& Chelliah, 2007).
$\mathrm{Zu}$ et al. (2018) found that the 5-phosphomevalonate kinase enzymes played important roles in enzyme squalene synthase (SS) in main roots of Panax notoginseng and he has also found, the enzyme squalene synthase (SS) in main roots of $P$. notoginseng under different arsenic treatment concentrations in early flowering stage. The 5-phosphomevalonate kinase enzyme (5-PDase - EC 2. 7. 4. 2) Plays very important role in the indole alkaloid biosynthesis in the first pathway biosynthesis MVA which exists in many organisms (Goldstein \& Brown, 1990).

In this study, the 5-phosphomevalonate kinase enzyme response to gamma rays and its relation to the accumulation of Ajmalicine production in cell suspension cultures of $C$. roseus were investigated.

\section{Materials and Methods}

Catharanthus rouses. (L). plant seeds were washed with tap water, then the seed surface was sterilized by soaking for $15 \mathrm{~min}$ in $30 \%$ clorox, 
and washed to remove any residues of clorox. They were placed in jars contained water agar free hormones. The cultured jars were incubated in a growth chamber at $\left(26 \pm 2^{\circ} \mathrm{C}\right)$ at day and $22^{\circ} \mathrm{C}$ at night under a photoperiod of $16 \mathrm{hr} /$ day of 2000 LUX intensity (Constable et al., 1981).

After three weeks of culture, leaves buds 1.5-2.0mm in length of seedling $C$. roseus, were selected from seedlings and placed with the MS media supplemented with $1.0 \mathrm{mg} \alpha$ - naphthalene acetic acid (NAA) $+1.0 \mathrm{mg}$ N6 - Benzyle adenine (BA)/L. with $0.8 \%$ agar, with $8 \%$ sucrose $\mathrm{pH} 5.8$ in jars, cultures were incubated at the previous conditions, within 4 weeks were $75 \%$ of the callus were induced. After 7 weeks individual calli was serially sub cultured by transfer to maintenance medium consisting of Gamborg's B5 medium supplemented $1.0 \mathrm{mg} / \mathrm{L}$ 2,4-dichlorophenoxyacetic acid $(2,4 \mathrm{D})$ and $0.1 \mathrm{mg} / \mathrm{L}$ with $2 \%$ sucrose, $\mathrm{pH}$ 5.8 for 4 weeks on gyratory shakers (130) rpm according to method Morris et al. (1989). Then cell suspension were irradiated by gamma ray at dose levels of $1,1.5,2,2.5,3,3.5,4,4.5,5,5.5,6$, $6.5,7,7.5$ and $8 \mathrm{~Gy}$, the source used was ${ }^{137} \mathrm{Cs}$ with a dose rate of $0.43 \mathrm{~Gy} / \mathrm{min}$ and the last untreated dose considered as control for comparion.

\section{Media alkinazation}

Alkinazation of the media was measured by the $\mathrm{pH}$ meter after irradiating the tretments and control (unirradiated), within 120min (every 10 min) for each sample.

\section{Enzyme assay}

Extraction of 5-phosphomevalonate kinase enzyme

After 2 weeks from irradiation, according to Schulte et al. (1999), extract of crude was prepared by homogenizing $50 \mathrm{~g}$ frozen biomass in pre cooled a blender by liquid nitrogen, in the presence of polyvinylpolypyrrolidone $(10 \% \mathrm{wt} / \mathrm{fr}$. wt) and extraction buffer $[0.1 \mathrm{M}$ Tris-Hcl, $\mathrm{pH} 7.5,0.1 \mathrm{M}$ sucrose, $50 \mathrm{mM} \mathrm{KCl}, 5 \mathrm{mM}$ dithiothreitol (DTT)] $2 \mathrm{ml}$ buffer/ $\mathrm{L} \mathrm{g}$ fr. wt. Then, at $30^{\circ} \mathrm{C}$, each sample was vortexed for $15 \mathrm{sec}$ and centrifuged for $30 \mathrm{~min}$ at $2600 \mathrm{~g}$. at $4^{\circ} \mathrm{C}$. The supernatant was transferred to new Eppendorf tube and filtered over glass fiber filter (Millipore-UK) and concentrated by a concentrator equipped by a membrane $(30 \mathrm{kDa}$. Cutoff, pall-filtron Dreieich, Germany.), the concentrated extract was kept at $-80^{\circ} \mathrm{C}$ in liquid nitrogen to be used for purification step.

\section{Purification of enzyme}

Twelve Samples (a control and 11 irradiated). Each sample was about $20 \mathrm{ml} /$ fraction, the protein concentration was conflicting commensurate with the irradiation treatments. By using size exclusion chromatography (SEC), the enzyme purification in a system of (Buchler column chromatography, fracto scan UV monitor system model (3$5101)$, the eluted fractions were monitored by absorbance at $280 \mathrm{~nm}$., LC 26 column (2.6i. d. $\times 65 \mathrm{~cm}$ - gel volume $\left.345.1 \mathrm{~cm}^{3}\right)$. The medium used is G50 - Coarse, (GE Healthcare); the column was equilibrated by extraction buffer without DTT, and run at $1 \mathrm{ml} / \mathrm{min}$, the fraction collector was adapted at $1 \mathrm{ml} / \mathrm{min} /$ fraction; high molecular weight $1000 \mu 1$ (GE Healthcare) used for calibrating SEC column, (Ovalbumin 44000, Conalbumin 75000, Aldolase 158000, Ferritin 440000, Thyroglobulin 665000 and Blue Dextron 2000). The samples collected were concentrated to $10 \mathrm{ml}$, nearly by ultra filtration $(50 \mathrm{kDa}$. Cutoff, pall-Filtron Dreieich, Germany).

5-Phosphomevalonate kinase (PMK) enzyme assay

The different tretments were collected from the SEC were used for the determination of the PMK activity of Schulte method (Schulte et al., 1999), the syntheses of mevalonate 5-phosphate and mevalonate 5-diphosphate has been previously reported by Herdendorf \& Miziorko (2007). Protein concentration of samples was determined using the Bradford micro assay method (Bradford, 1976).

Native-polyacrylamide gel electrophoresis (Native-PAGE)

According to Schulte et al. (1999) NativePAGE was used to study the identification of the samples by 5-PDase enzyme finger prints. Samples of enzyme fractions peaks containing PMK activity which was eluted. A volume of $50 \mu \mathrm{l}$ extract of each sample was mixed with $10 \mu \mathrm{l}$ bromophenol blue, and then, a volume of $60 \mu$ l of this mixture was applied to each well. The gels were stained after electrophoresis according to Silver Quest ${ }^{\mathrm{TM}}$ Silver Staining Kit system.

\section{Ajmalicine determination}

Twelve samples previous prepared (a control and 11 irradiated treatments) to analyze the Ajmalicine component in C. roseus. Cell culture by UV - VIS spectrophotometer Shimadzu 120 $\mathrm{UV}-02$. at $510 \mathrm{~nm}$, Ajmalicine $(100 \mathrm{mg})$ of pure, 
authentic Ajmalicine (Sigma) was dissolved in $10 \mathrm{ml}$ of methanol and diluted to the volume with double-distilled water in a $100 \mathrm{ml}$ standard flask, as stock, a standard solution was kept in dark bottles at $4^{\circ} \mathrm{C}$. Further, $0.025 \mathrm{M}$ iron (III) chloride in $0.5 \mathrm{M} \mathrm{HCl} \mathrm{kept} \mathrm{in} \mathrm{dark} \mathrm{bottles} \mathrm{at} 4^{\circ} \mathrm{C}$. and $0.05 \mathrm{M}$ solution of 1,10 phenanthroline in methanol and kept in dark bottles at $4^{\circ} \mathrm{C}$ (Singh et al., 2004).

Different concentrations of stock standard solutions $0.0,1.0,2.0,3.0,4.0,5.0,6.0,7.0,8.0$, 9.0, 10.0, 11.0, and $12.0 \mathrm{ml}$ of Ajmalicine were transferred into a 13 flask of $25 \mathrm{ml}$ standard, then added $1 \mathrm{ml}$ of $\mathrm{FeCl}_{3}$ solution and $1 \mathrm{ml}$ of a 1, 10phenanthroline solution, and diluted with water. The flask was placed in a water bath at the $70^{\circ} \mathrm{C}$ for $30 \mathrm{~min}$. The absorbance of the red-colored produced was measured at $510 \mathrm{~nm}$ against a blank reagent.

\section{Application of sampling}

Extraction of alkaloids from the cells

Samples previously prepared, (a control and 11 irradiated treatments) in 12 flask each 60 and $120 \mathrm{~min}$ (total flask 24), were used to analyze the ajmalicine component in C. roseus. Cell culture was conducted as follows; $100 \mathrm{mg}$ of freeze dried cell material with $15 \mathrm{ml}$ of methanol using an ultra turrax (Ystral, Ballrechten, Germany). then centrifugation at $3500 \mathrm{~g}$ for $30 \mathrm{~min}$, the methanolic extract was reduced to dryness under reduced vacuum, the residues were dissolved in water and the alkaloids were extracted into ethyl acetate, followed by concentration under vacuum (Lucumi et al., 2002). The ethyl acetate was removed and the residues were dissolved in ethanol, then added $1 \mathrm{ml}$ of $\mathrm{FeCl}_{3}$ solution and $1 \mathrm{ml}$ of a 1, 10phenanthroline solution each of the flask, and diluted to the mark with water. At the end, the flask was placed in a water bath maintained at the $70^{\circ} \mathrm{C}$ for $30 \mathrm{~min}$ (Singh et al., 2004).

\section{Extraction of alkaloids from the medium}

Twenty $\mathrm{ml}$ of medium, (a control and 11 irradiated treatments) in 12 flask each 60 and 120min (total flask 24), to analyze the Ajmalicine accumulation in medium of $C$. roseus. cell culture was adjusted to the $\mathrm{pH}$ value of 10 , then $10 \mathrm{ml}$ ethyl acetate was added to the flask of medium using an ultra turrax (Ystral, Ballrechten, Germany). The ethyl acetate was removed by evaporation, the residues were filtrated and dissolved in ethanol (Zhao et al., 2001). Then, $1 \mathrm{ml}$ of $\mathrm{FeCl}_{3}$ solution and $1 \mathrm{ml}$ of a 1,10 - phenanthroline solution each of the flask were added, and diluted to the mark with water. At the end, the flask was placed in a water bath maintained at the $70^{\circ} \mathrm{C}$ for $30 \mathrm{~min}$ (Singh et al., 2004). The absorbance of the redcolored products from both cells and medium was measured at $510 \mathrm{~nm}$ on VIS - spectrophotometer.

\section{$\underline{\text { Results and Discussion }}$}

\section{Cell survivor and medium alkinazation}

Irradiation of $C$. Roses cell suspensions with a dose level higher than 6Gy of gamma rays resulted in a significant mortality of these cells, no data were obtained after the exposure of cell suspension to a dose level exceeding 6Gy.

Figure 1 shows that the $\mathrm{pH}$ values of the cell suspension cultures (control, 3.5Gy and 6Gy) recorded, the $\mathrm{pH}$ values were increased gradually by increasing the applied dose. This increase in the $\mathrm{pH}$ values were changed by applying different time intervals .

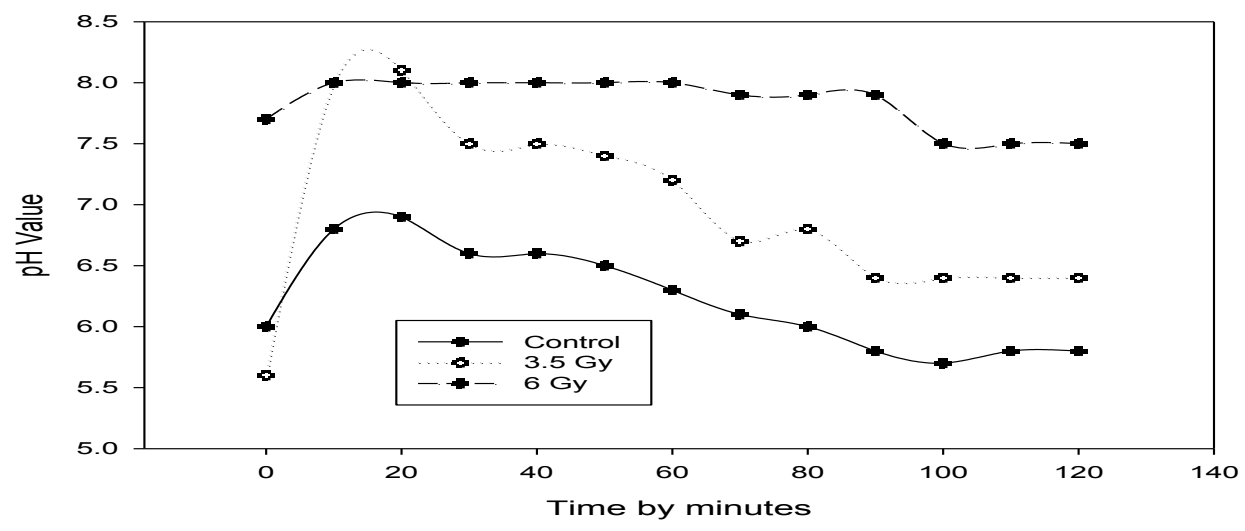

Fig. 1. pH values detected after irradiation cell suspension of $C$. roseus with different dose levels of gamma rays. 
The obtained results are in agreement with Ramani \& Chelliah (2007) who found that the $\mathrm{pH}$ values of $C$. roseus cell suspension, increased after irradiation with UV rays for $5 \mathrm{~min}$ and the value decreased after that. Also, they reported that the increase of $\mathrm{pH}$ values affects directly the charged and polarity of the cell surfaces and activates MPK enzyme. This enzyme could be increased the indole alkaloids through RNA transcription in the cell nucleus.

\section{5-phosphomevalonate kinase enzyme activity}

The 5-phosphomevalonate kinase enzyme (PMK) elution pattern was purified by G50 Coarse, medium as shown in Fig. 2, there were 7 peaks, and the PMK enzyme activity was in the fourth peak. The elution volume fourth peak was commensurate with the irradiation treatments; for instance the elution volume fourth peak (by $\mathrm{ml}$ ) in 0 dose (control), 1, 1.5, 2, 2.5, 3, 3.5, 4, $4.5,5,5.5$ and $6 \mathrm{~Gy}$ were $170,173,176,182$, 180, 190, 186, 204, 210, 202, 203 and 204kDa, respectively approximately.

The mid fractions of four peaks estimate the molecular weight, PMK enzyme corresponds to a protein with an MW of about between 75 and $156 \mathrm{kDa}$. with intermediate $115 \mathrm{kDa}$. approximately (Fig. 2), the PMK enzyme activity and other characters were conflicting commensurate with the irradiation treatments (Table 1).

The highest value in volume of peak containing PMK activity $(10 \mathrm{ml})$ was $1 \mathrm{~Gy}$, and lowest $(7 \mathrm{ml})$ were 3 and $5 \mathrm{~Gy}$. The highest value in total protein concentration in PMK activity peak $(2 \mathrm{mg})$ was $1 \mathrm{~Gy}$, and the lowest $(0.9 \mathrm{mg})$ were 2.5 and $4.5 \mathrm{~Gy}$.

The highest value in total activity of PMK enzyme $(22 \mathrm{nmol} / \mathrm{min})$ was $1 \mathrm{~Gy}$, and the lowest $(0.09 \mathrm{nmol} / \mathrm{min})$ was $4.5 \mathrm{~Gy}$. The highest value in specific activity $(0.15 \mathrm{nmol} / \mathrm{min} / \mathrm{mg})$ was $2 \mathrm{~Gy}$, and the lowest $(0.1 \mathrm{nmol} / \mathrm{min} / \mathrm{mg})$ was $3.5 \mathrm{~Gy}$. Also, the highest value in purification factor (1.3) was $3 \mathrm{~Gy}$, and the lowest (0.8) was $4.5 \mathrm{~Gy}$, on the other hand the highest value in yield (183) was $1 \mathrm{~Gy}$, and the lowest (75) was 4.5Gy. In general, the maximum value in characters of PMK enzyme (Table 2) was achieved at $1 \mathrm{~Gy}$, on the other hand, the minimum value in characters of PMK enzyme was achieved at 4.5Gy.
Native-polyacrylamide gel electrophoresis (Native-PAGE)

Resultes shown in Table 2 and Fig. 3 reveal the effects of $\gamma$ ray on the protein bands which are contented 5-PDase-EC 2. 7. 4. 2 enzymes clearly, showed the increase in numbers, denisty and molecular weight of protein bands, respectively with increasing of dose level. The data showed that the irradiation of cell suspensions of $C$. roseus resulted in the following bands. Band no. 1 with molecular weight $97 \mathrm{kDa}$. was absent in treatments from 0 to 3.5 and $5.5 \mathrm{~Gy}$, but this band appeared in treatments from 4 to $6 \mathrm{~Gy}$. Thus, it could be used as molecular marker for this treatment which appear in it. Also, band no. 3 with molecular weight $66 \mathrm{kDa}$. was absent in treatments from 0 to 3.5 and $5.5 \mathrm{~Gy}$, but this band appeared in treatments from 4 to 6Gy. So, it could be used as molecular marker for this treatment which appear in it. Band no. 5 with molecular weight $55 \mathrm{kDa}$. was absent in treatment $(1 \mathrm{~Gy})$, but this band appeared in all other treatments. Band no. 6 with molecular weight $50 \mathrm{kDa}$. was absent in all treatments, but a unique band appeared in 3.5 Gy treatment. So, it could be used as molecular marker for this treatment. Band no. 8 with molecular weight $40 \mathrm{kDa}$. was absent in treatments $0,2.5$ and $3 \mathrm{~Gy}$, but this band appeared in other treatments. Band no. 9 with molecular weight $35 \mathrm{kDa}$. was absent in all treatments, but this band uniquely appeared in treatment 3.5Gy. Therefore, it could be used as molecular marker for this treatment. Band no. 16 with molecular weight $30 \mathrm{kDa}$. appeared in treatments $0,1,2,2.5$ and $3 \mathrm{~Gy}$, but this band was absent in other treatments. So, it could be used as molecular marker for this treatment which appear in it. The bands no. 2, 12, 17 \& 18 with molecular weight $70,33,28$ and $24 \mathrm{kDa}$. appeared in all treatments.

Generaly the dose levels $0,1,1.5,2.5,3$ and $5.5 \mathrm{~Gy}$ were similar in total numbers of bands (bands 6), but the bands in each line were differences in molecular weight and intensity compare control; the doses 3.5, 4, 4.5, 5 and 6Gy were similar in numbers of bands ( 8 bands), but the bands in each line were different in molecular weight and intensity compared to control. On the other hand, the level dose $2 \mathrm{~Gy}$ was different completely in total number of bands (band 7), intensity and molecular weight compare control and other treatments (Table 2 and Fig. 3). 

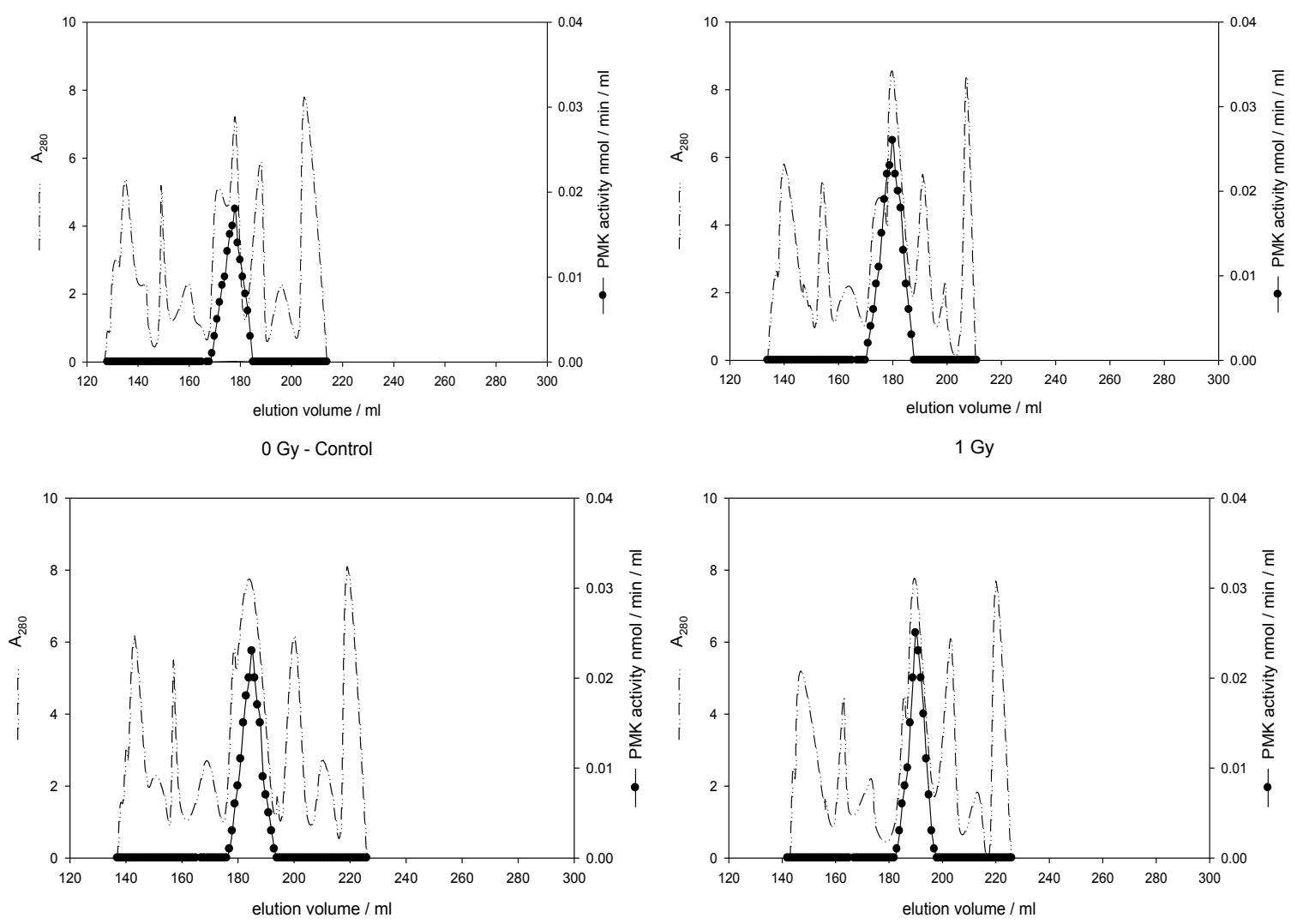

$1.5 \mathrm{~Gy}$
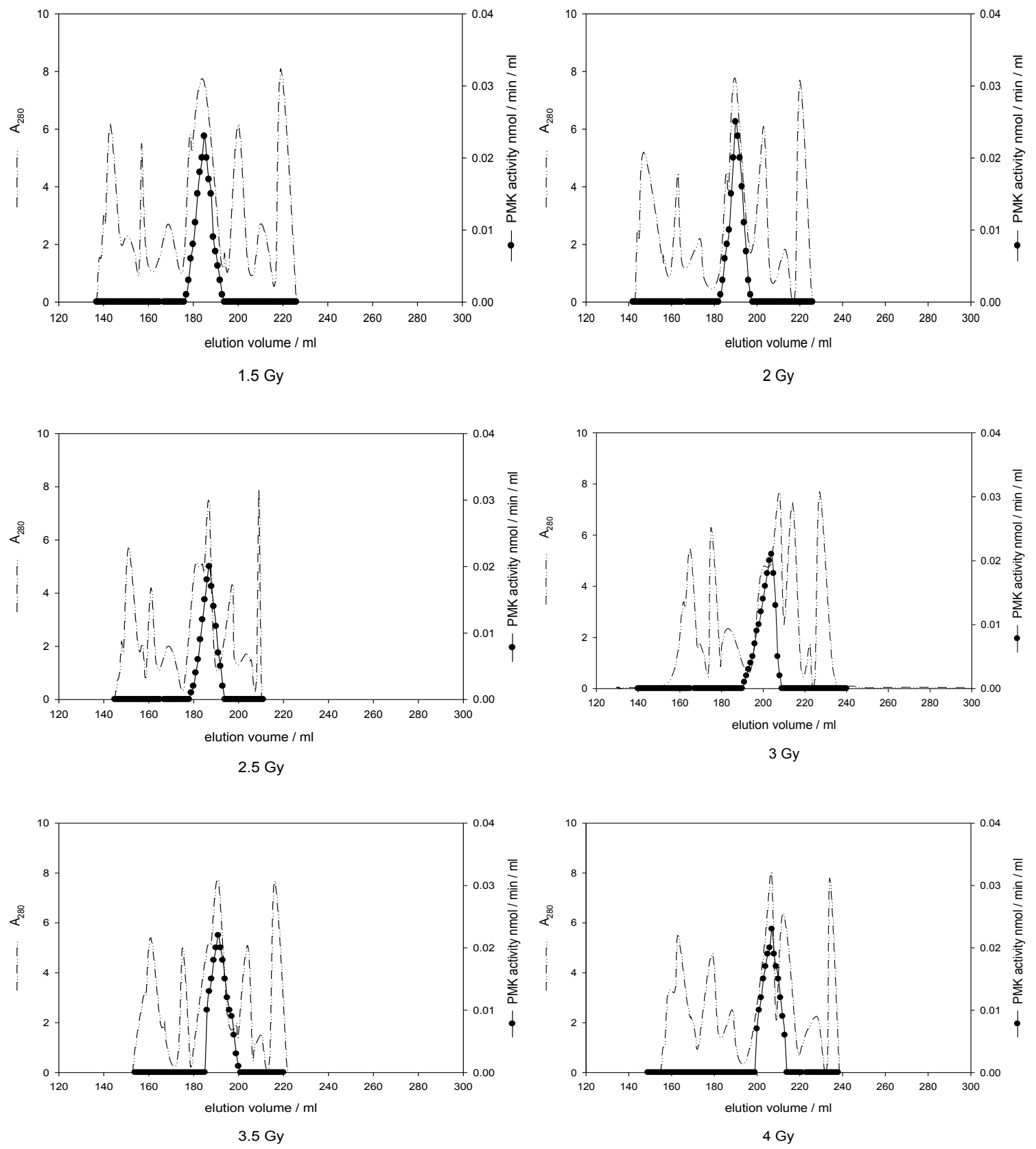

Egypt. J. Rad. Sci. Applic. 32, No.1 (2019) 

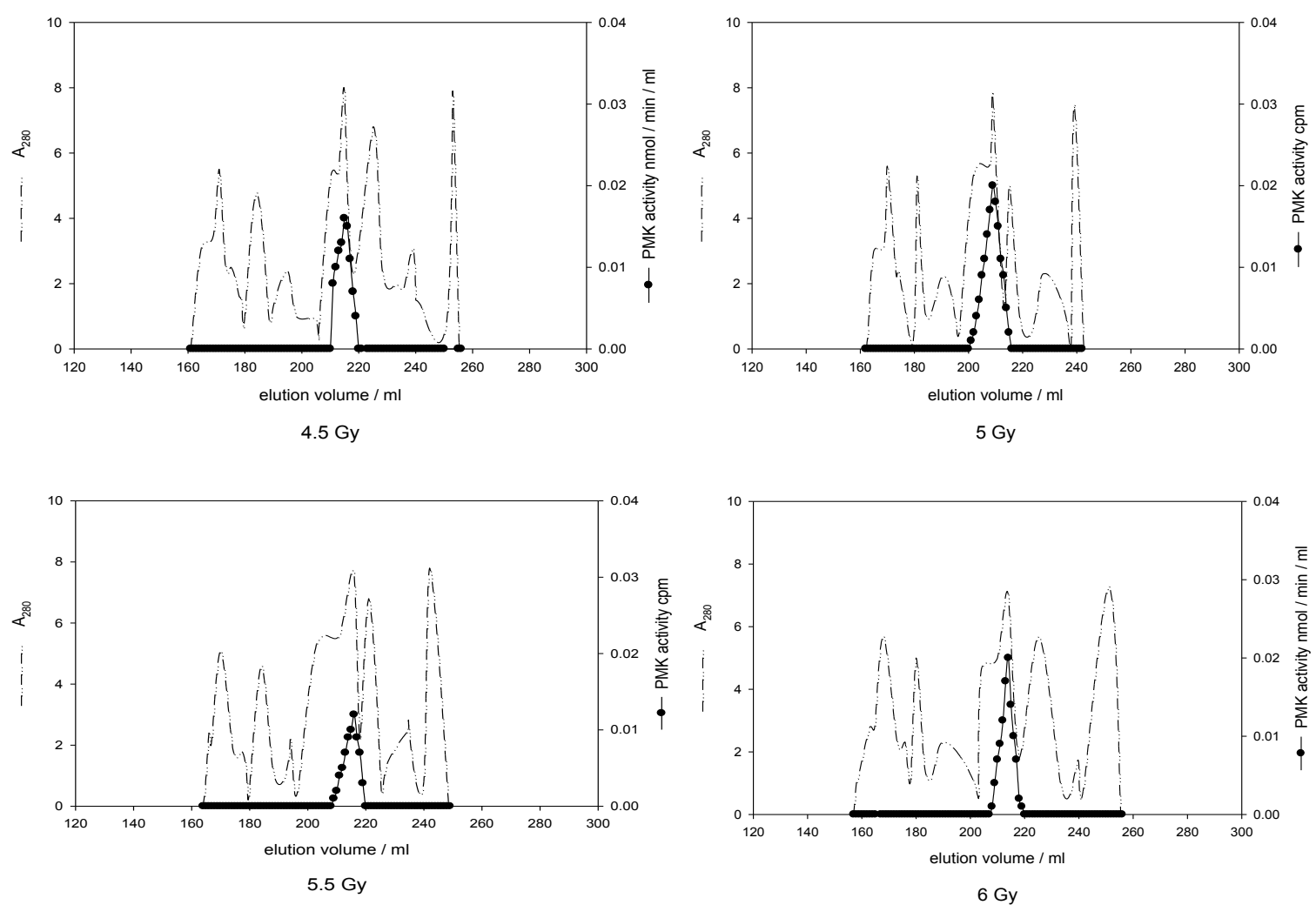

Fig. 2. Chromatographic patterns obtained by passing several enzymes, including 5-phosphomevalonate kinase enzyme (PMK) from $C$. roseus. suspension culture cells, preparations through a column $2.6 \mathrm{i} . \mathrm{d} . \times 65 \mathrm{~cm}-\mathrm{gel}$ volume 345.1 $\mathrm{cm}^{3}$ of G50-Coarse, medium (SEC) [The PMK enzyme was elution and determinate of activity $\mathrm{nmol} /$ $\min / \mathrm{ml}]$.

TABLE 1. Purification of 5-phosphomevalonate kinase from enzyme (PMK) from $C$. roseus. suspension culture cells.

\begin{tabular}{|c|c|c|c|c|c|c|c|c|}
\hline $\begin{array}{l}\text { Treatments } \\
\text { by Gy }\end{array}$ & $\begin{array}{c}\text { Total protein } \\
\text { concentration } \\
(\mathrm{mg})\end{array}$ & $\begin{array}{c}\text { Volume } \\
\text { of peak } \\
\text { containing } \\
\text { PMK } \\
\text { activity by } \\
\text { ml }\end{array}$ & $\begin{array}{c}\text { Total protein } \\
\text { concentration } \\
\text { in PMK activity } \\
\text { peak }\end{array}$ & $\begin{array}{c}\text { Total activity } \\
\text { of PMK } \\
\text { enzyme } \\
\text { in peak } \\
\text { containing it's } \\
\text { activity } \\
\text { nmol/min }\end{array}$ & $\begin{array}{c}\text { Specific } \\
\text { activity } \\
\text { nmol/min/ } \\
\text { mg }\end{array}$ & $\begin{array}{l}\text { Purification } \\
\text { factor }\end{array}$ & $\begin{array}{l}\text { Yield } \\
100 \%\end{array}$ & $\begin{array}{c}K_{d} \\
\text { beak } \\
\text { containing } \\
\text { PMK } \\
\text { activity }\end{array}$ \\
\hline Control & 4.0 & 8 & 1 & 0.12 & 0.12 & 1.00 & 100 & 0.6 \\
\hline 1 & 4.1 & $10^{*}$ & $2 *$ & $0.22 *$ & 0.11 & 0.92 & $183^{*}$ & 0.6 \\
\hline 1.5 & 3.8 & 8 & 1.2 & 0.16 & 0.13 & 1.10 & 133 & 0.5 \\
\hline 2 & 4.6 & 8 & 1.5 & 0.18 & 0.12 & 1.00 & 150 & 0.5 \\
\hline 2.5 & 3.7 & 7.5 & 0.9 & 0.10 & 0.11 & 0.92 & 83 & $0.7^{*}$ \\
\hline 3 & 4.7 & 7 & 1.2 & 0.15 & $0.15^{*}$ & $1.30^{*}$ & 125 & 0.5 \\
\hline 3.5 & $4.8^{*}$ & 7.5 & 1.5 & 0.19 & 0.13 & 1.10 & 158 & 0.5 \\
\hline 4 & 4.6 & 8 & 1.3 & 0.16 & 0.12 & 1.00 & 133 & 0.5 \\
\hline 4.5 & 3.8 & 9 & 0.9 & 0.09 & 0.10 & 0.80 & 75 & 0.5 \\
\hline 5 & 4.0 & 7 & 1.1 & 0.14 & 0.13 & 1.10 & 116 & 0.4 \\
\hline 5.5 & 3.9 & 8.5 & 1 & 0.11 & 0.11 & 0.92 & 92 & 0.5 \\
\hline 6 & 4.2 & 8 & 1.1 & 0.13 & 0.12 & 1.00 & 108 & 0.4 \\
\hline
\end{tabular}

*: The high value, $\mathrm{K}_{d}$ : Distribution constant 


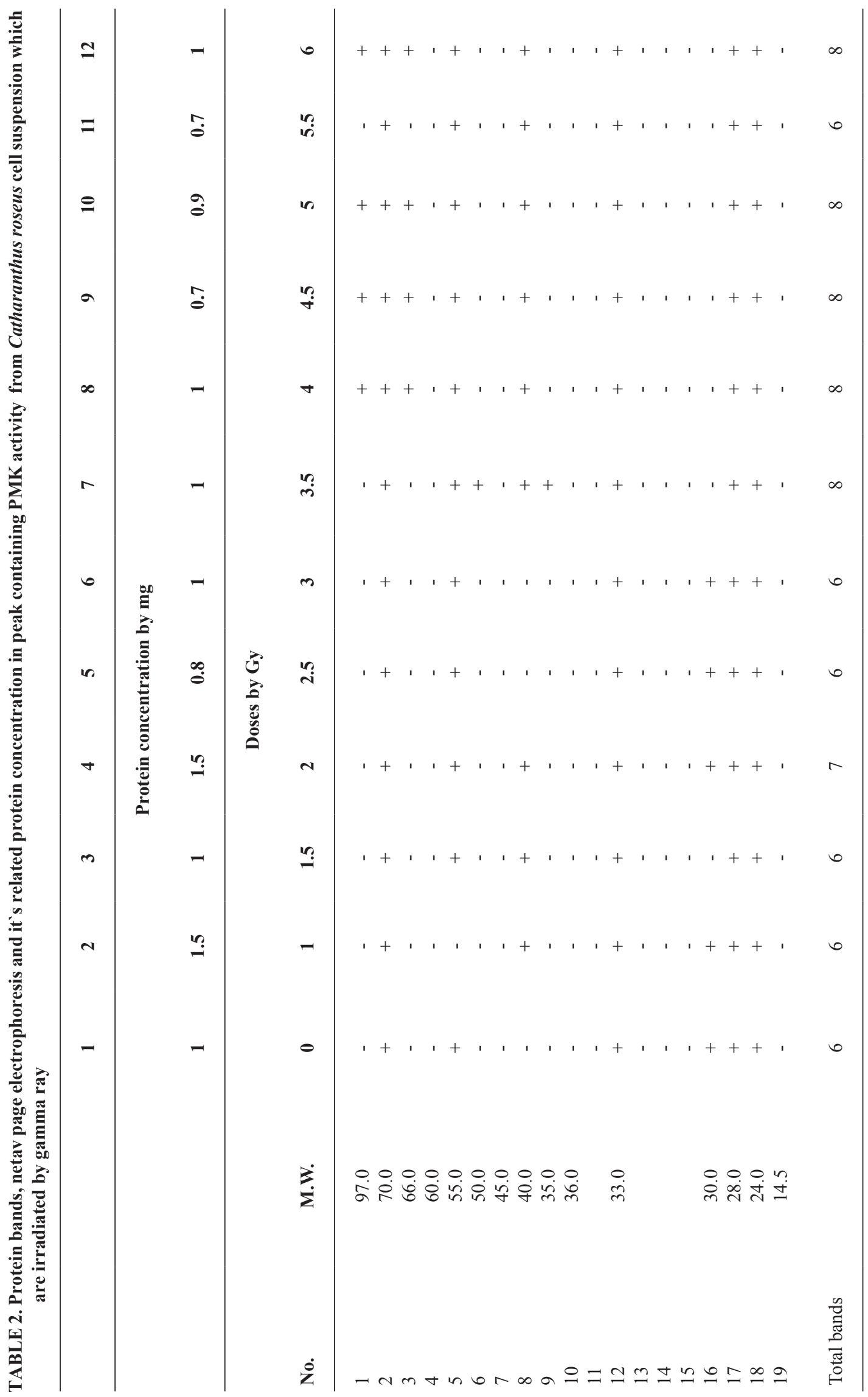

Egypt. J. Rad. Sci. Applic. 32, No.1 (2019) 


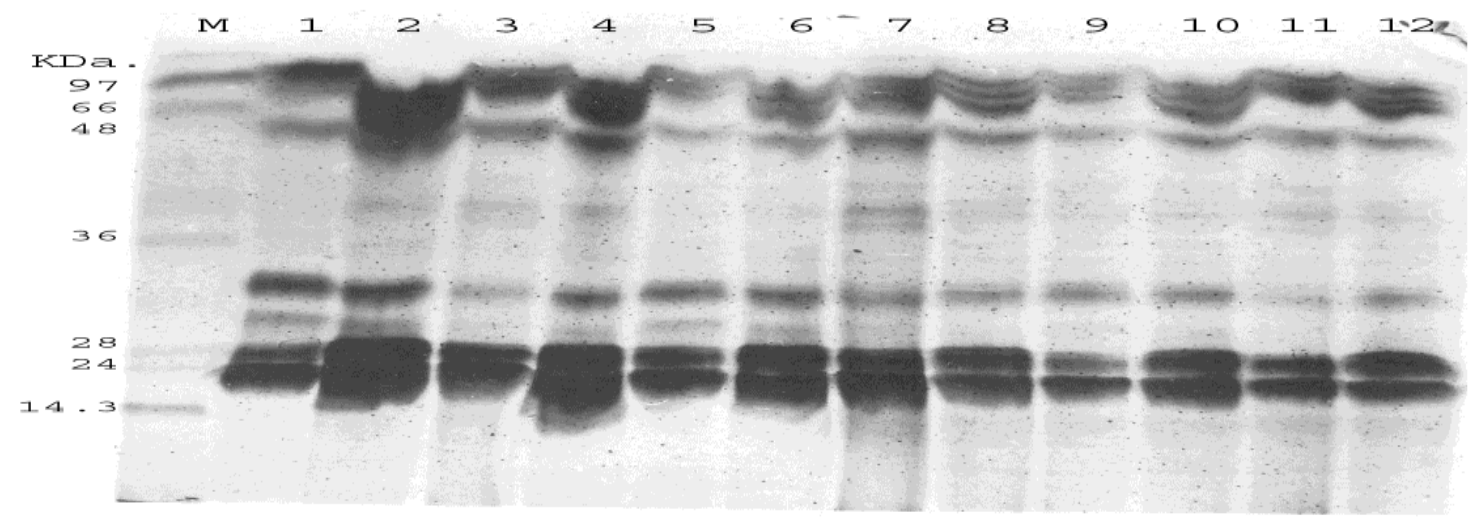

Fig. 3. Native PAGE of particularly purified 5-phosphomevalonate kinase enzyme in fourth Peak containing PMK activity from $C$. roseus cells suspension culture watch is irradiated by gamma ray.

The present results are in agreement with Schulte et al. (1999) in molecular weight bands, intensity bands and total number of bands which appeared after radiation treatment. The present results showed the appearance of total number bands among 6,7 and 8 bands, but the result of Schulte et al. (1999) demonstrated five bands only in the Native-polyacrylamide gel electrophoresis. On the other hand, the results of the present study revealed three bands as candidates containing PMK enzyme 97, 70 and $66 \mathrm{kDa}$. The band of $97 \mathrm{kDa}$ probably corresponds with a PMK enzyme, and the bands of 70 and $66 \mathrm{kDa}$ indicated a correspondance with a PMK enzyme (Table 2 and Fig. 3).

\section{Ajmalicine analysis}

Figures 4 and 5 show the value of ajmalicine accumulation in cellular and external cellular (in medium) after being irradiated in 60 and $120 \mathrm{~min}$. The biosynthesis of ajmalicine increased generally after exposure to the $\gamma$ ray elicitor directly in cells or medium. The increase of the ajmalicine production was gradually in both of them. The high increase in internal cells after $60 \mathrm{~min}$ was at the $4.5 \mathrm{~Gy}$ dose level, but in external cells (in medium), the highest value was at $1.5 \mathrm{~Gy}$ dose level, and after that previous dose, the ajmalicine accumulation decreased in the internal cells and external cells (in medium). However, the total ajmalicine accumulation was recorded at 3.5Gy dose level. On the other hand, the highest increase in internal cells was recorded after $120 \mathrm{~min}$ were at the $4 \mathrm{~Gy}$ dose level, but in external cells (in medium) the highest value was at a dose level of $3.5 \mathrm{~Gy}$, and after that previous dose, the ajmalicine accumulation decreased in the internal cells and external cells (in medium).
However, the total ajmalicine accumulation recorded at 3.5Gy dose level.

The results shown in Fig. 4 and 5 reveal a similarity between internal cellular ajmalicine accumulation and total ajmalicine (internal cellular and external cellular in medium) and compatibly in the carve behavior. On the other hand, there was no similarity between internal cellular ajmalicine accumulation and total ajmalicine (internal cellular and external cellular in medium), nevertheless no compatibly in the carve behavior between them.

These results show the relationship between the response of PMK enzyme to gamma ray, and terpenoid biosynthesis, the number and intensity of bands in SDS-PAGE electrophoresis, which were in their highest vlues in 3.5, 4 and 4.5Gy dose levels. The total ajmalicine accumulation after 60 and $120 \mathrm{~min}$ in ether internal cells or external cells was at 4.5 and $3.5 \mathrm{~Gy}$ dose levels, respectively. These results are due to the response of all enzymes, especially isoprenoid biosynthesis enzymes in both two bath way systems (MVA and MEP) in the cell.

These results are in agreements with Ouwerkerk et al. (1999) who irradiated the C. roseus seedling and studied both TDC and STR genes under radiation stress. They found accumulation of TIAs in C. roseus in response to UV light. Three-week old seedlings were irradiated with a $2 \mathrm{~min}$ UV light, seedlings were collected $24 \mathrm{hr}$ after UV light treatment and extracts were made for HPLC analysis of TIA contents. 


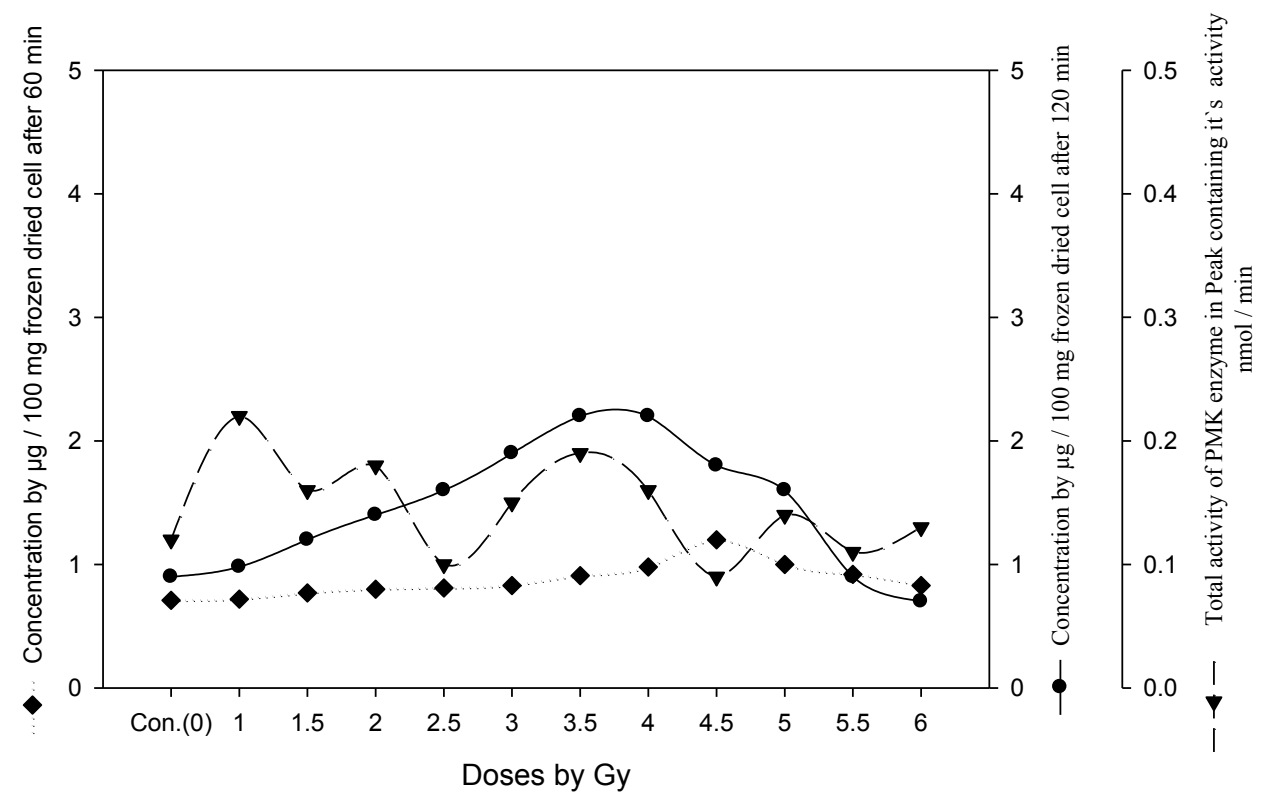

Fig. 4. Change of Ajmalicine accumulation and change in PMK activity under gamma radiation stress in internal cells after 60 and $120 \mathrm{~min}$.

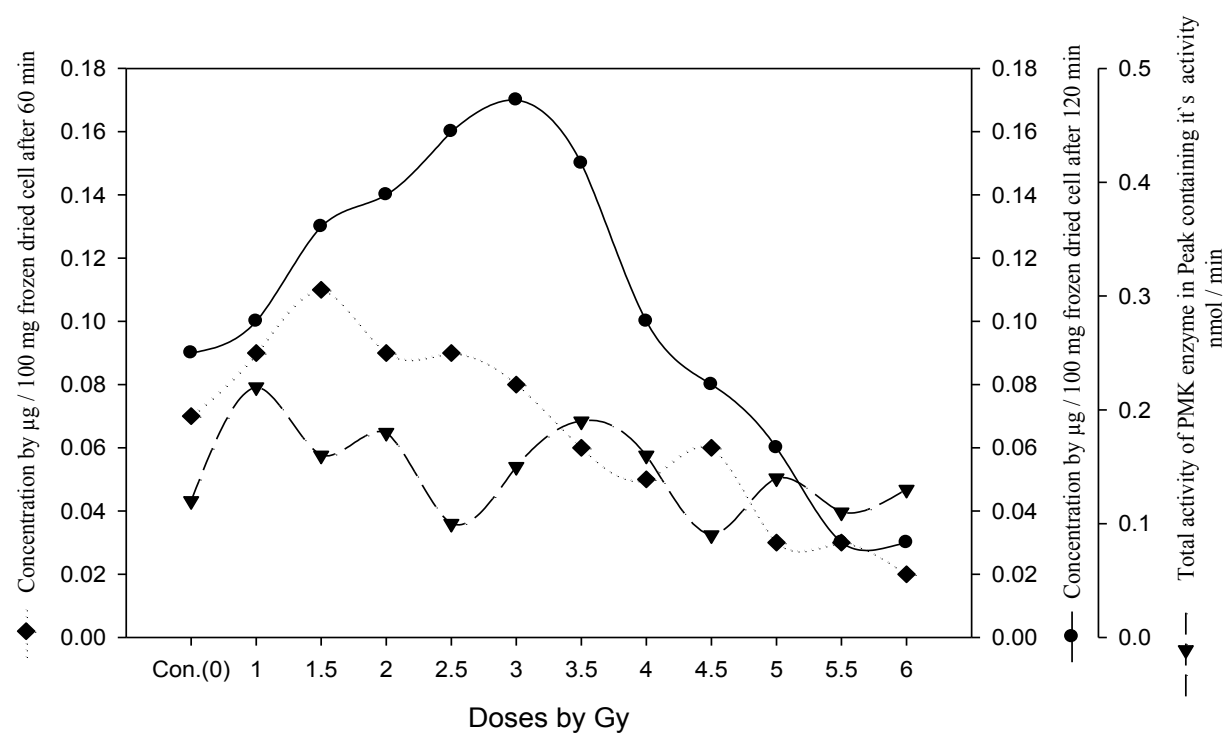

Fig. 5. Change of Ajmalicine accumulation and change in PMK activity under gamma radiation stress in external cells after 60 and $120 \mathrm{~min}$.

Ramani \& Chelliah (2007) reported that the UV ray effect the charge active membrane in the cell though changing permeability of the membrane. The increase of the $\mathrm{pH}$ medium after irradiatiation resulted in ion fluxes such as $\mathrm{Ca}^{+}, \mathrm{H}^{+}$and efflux ion such as $\mathrm{Cl}^{-}$. Therefore, this operation is responsible for the partial removal of the permeability of the membrane. All enzymes and especially kinase enzymes response to the ion fluxes/efflux is responsible for transfer the phosphate atom from ATP to 5- phosphomevalonate kinase then, it is transferred to 5-diphosphomevalonate.
Hirata et al. (1993) studied the effects of near-ultraviolet light on alkaloid production in Catharanthus roseus plants. UV-A and UV-B plant irradiation leads to a change of the compounds and putative functions in plants. These results were supported by the observation that UV light induces modification in TIAs biosynthesis in C. roseus. leaves.

\section{Conclusion}

The results of the current study clearly show the 
effect of gamma radiation on the protein bands including 5-PMKase enzyme and increasing the ajmalicine production in $C$. rouses. The result revealed that the gamma ray affects the accumulation of secondary metabolites in plant cell suspension culture so that it occurs in a late stage. The gamma ray leads to activating the 5-PMKase and changes medium alkalization. Electromagnetic waves such as $\gamma$ ray induces a change of cell compounds and putative functions in plants including protection against electromagnetic waves .

\section{$\underline{\text { References }}$}

Aerts, R.J., Alarco, A.M. and De Luca, V. (1992) Auxins induce tryptophan decarboxylase activity in radicles of Catharanthus seedlings. Plant Physiol. 100(2), 1014-1019.

Bach, T.J. (1995) Some new aspects of isoprenoid biosynthesis in plants a review. Lipids, 30(3), 191202.

Bradford, M.M. (1976) A rapid and sensitive method for the quantitation of microgram quantities of protein utilizing the principle of protein-dye binding. Analytical Biochemistry, 72, 248-254.

Constable, F., Rambold, S., Chatson, K.B., Kurz, W.G. and Kutney, J.P. (1981) Alkaloid production in Catharanthus roseus (L.) G. Don.: VI. Variation in alkaloid spectra of cell lines derived from one single leaf. Plant Cell Rep. 1(1), 3-5.

Goldstein, J.L. and Brown, M.S. (1990) Regulation of the mevalonate pathway. Nature, 343(6257), 425430 .

Herdendorf, T.J. and Miziorko, H.M. (2007) Functional evaluation of conserved basic residues in human phosphomevalonate kinase. Biochemistry, 46(42), 11780-11788.

Hirata, K., Asada, M., Yatani, E., Miyamoto, K. and Miura, Y. (1993) Effects of near-ultraviolet light on alkaloid production in Catharanthus roseus plants. Planta Med. 59(1), 46-50.

Lichtenthaler, H.K., Rohmer, M. and Schwender, J. (1997) Tow independent biochemical pathways for isopentenyl diphosphate and isoprenoid biosynthesis in higher plants. Physiologia Plantarum, 101(3), 643-652.

Lucumi, E., Vera, A., Hallard, D, van der Heijden,
R. and Verpoorte, R. (2002) Alkaloid formation in cell suspension cultures of Tabernaemontana elegans after feeding of tryptamine and loganin or secologanin. Plant Cell, Tissue and Organ Culture, 68(3), 293-299.

Morris, P., Rudge, K., Cresswell, R. and Fowler, M.W. (1989) Regulation of product synthesis in cell culture of Catharanthus roseus. V. Long-term maintenance of cells on a production medium. Plant Cell Tiss. Org. Cult. 17(2), 79-90.

Ouwerkerk, P.B., Hallard, D., Verpoorte, R. and Memelink, J. (1999) Identification of UV-B light-responsive regions in the promoter of the tryptophan decarboxylase gene from Catharanthus roseus. Plant Molecular Biol. 41(4), 491-503.

Ramani, S. and Chelliah, J. (2007) UV-B-induced signaling events leading to enhanced-production of Catharanthine in Catharanthus roseus cell suspension cultures. BMC Plant Biol. 7, 61-78.

Schulte, A.E., Van der Heijden, R. and Verpoorte, R. (1999) Microplate enzyme-coupled assays of mevalonate and phosphomevalonate kinase from Catharanthus roseus suspension cultured cells. Anal. Biochem. 269(2), 245-254.

Singh, D.K., Srivastava, B. and Sahu, A. (2004) Spectrophotometric determination of Rauwolfia: Estimation of reserpine in pharmaceuticals. Analytical Sciences, 20(3), 571-573.

Zhao, J., Zhu, W. and Hu, Q. (2001) Selection of fungal elicitors to increase indole alkaloid accumulation in Catharanthus roseus suspension cell culture. Enzyme and Microb. Technol. 28(7-8), 666-672.

Zhao, J., Davis, L.C. and Verpoorte, R. (2005) Elicitor signal transduction leading to production of plant secondary metabolites. Biotechnol Adv. 23(4), 283333.

Zu, Y., Li, Z., Mei, X., Wu, J., Cheng, S., Jiang, Y. and Li, Y. (2018) Transcriptome analysis of main roots of Panax notoginseng identifies genes involved in saponin biosynthesis under arsenic stress. Plant Gene, 16, 1-7. 


\title{
إستجابة إنزيم 5ـ فسفوميفالونيت كينيز للجرعات المنخفضة من الاشعاع الجامي وعلاقة ذللك بأنتاجية تربينات قلويدات فئو الاندول في نبات الونكا \\ إسلام محمد سلامة السيد، جهاد محمد علي حسن، محمد حسن عبد المجيد قسم بحوث المنتجات الطبيعية ـ المركز القومي لبحوث وتهن وتكنولوجيا الإشعاع ـ الهيئة المصرية للطاقة الذرية ـ القاهرة - مصر.
}

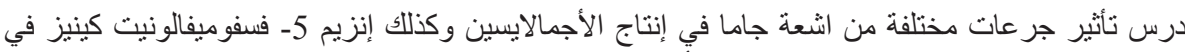

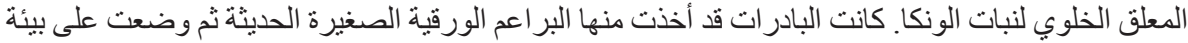

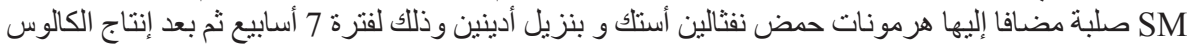

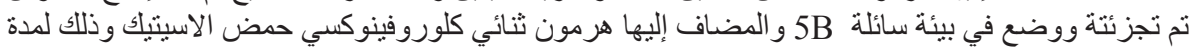

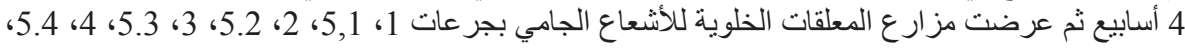

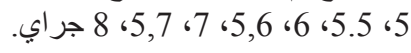

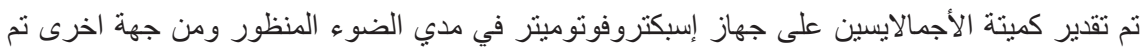

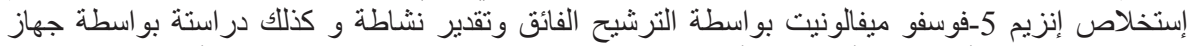

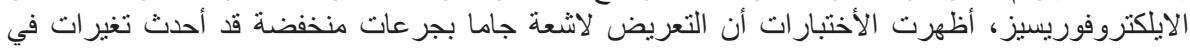

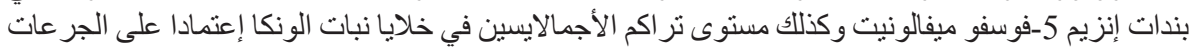

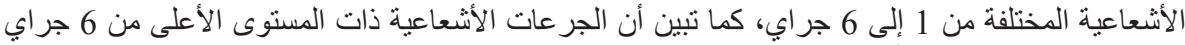

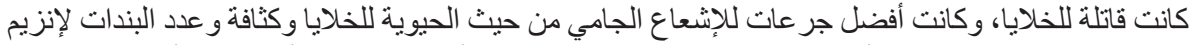

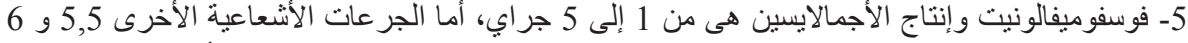

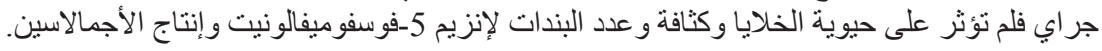

